\section{En enda bedre utgave av lærebok i statistikk fra Gunnar Løvås}

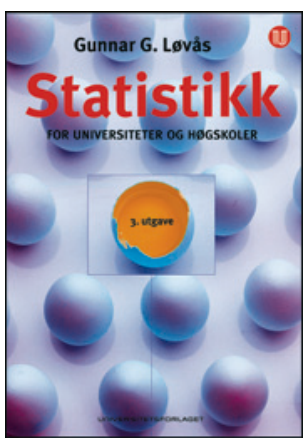

Gunnar G. Løvås

Statistikk for universiteter og høgskoler

3. utg. $542 \mathrm{~s}$, tab, ill. Oslo: Universitetsforlaget,

2013. Pris NOK 599

ISBN 978-82-15-01807-2

Løvås’ statistikkbok er skrevet for alle som ønsker å lære om sannsynlighetsteori og statistikk. Statistikk er et metodefag for de fleste natur- og samfunnsvitenskapelige disipliner, og boken er skrevet slik at den favner alle, også medisin og helsefag. Bokens fokus på metode, og ikke ett spesielt fag, inviterer leseren til tverrfaglighet.

Dette er en omfattende bok, og den er inndelt i seksjoner om sannsynlighetsteori, beskrivende statistikk og statistisk analyse. Hver seksjon inneholder flere kapitler. Den har også en seksjon om utvalgte anvendelser, slik som kvalitetsstyring og simuleringsteknikker. Løvås bruker god tid på å motivere leseren før han fokuserer på teori og definisjoner. Boken er også rik på eksempler og regneoppgaver. Tunge matematiske bevis har forfatteren plassert bakerst. Det er flere nye temaer i denne 3. utgaven, og det jeg liker best, er at boken inneholder korte og presise oppskrifter på hvordan vi kan bruke Excel, Minitab og SPSS i anvendelsen av de ulike metodene og modellene.

Boken er ikke skrevet spesielt for medisinsk og helsefaglig bruk, og den inneholder derfor ikke metoder som er typiske for disse fagene, slik som forløpsanalyse og logistisk regresjon. På den annen side gir boken en grundig innføring i regresjon generelt, og den inneholder også andre metoder og teknikker som er aktuelle også innen medisin og helsefag, for eksempel kvalitetsstyring og hendelsestrær.

Statistisk modellering har endret seg de siste årene. Ideer og begreper knyttet til det å trekke kausale slutninger er et viktig fundament for hvordan man skal sette opp statistiske modeller, og for hvordan vi skal tolke resultatene fra disse modellene. Dette er ikke inkludert i Løvås’ bok.

Boken er velskrevet, den er faglig grundig, og den har mye humor. Jeg vil absolutt anbefale den til lærere og studenter innen medisin og helsefaglige studier.

\section{Geir Aamodt}

Professor i epidemiologi, Norges miljø- og biovitenskapelige universitet

\section{Glimrende om overlevelse og hjelpetiltak etter foreldres selvmord}

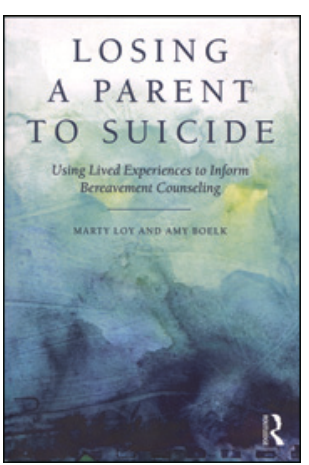

\author{
Marty Loy, Amy Boelk \\ Losing a parent to suicide \\ Using lived experiences to inform \\ bereavement counseling. $209 \mathrm{~s}$, tab, ill. \\ Hove: Routledge, 2014. Pris GBP 24 \\ ISBN 978-0-415-81618-2
}

Boken er basert på mangeårige erfaringer fra Camp HOPE (leirarrangement for barn i sorg) og en studie med 22 voksne deltakere som alle hadde mistet en forelder i selvmord under oppveksten. Studien undersøkte faktorer som fremmet og hemmet tilheling etter selvmord. Målgruppen er i utgangspunktet «counselors», som kanskje best kan sammenliknes med godt fungerende støtte- og rådgivningstjeneste i førstelinjetjenesten, samt noen av andrelinjetjenestens tilbud. Bokens innhold og budskap er imidlertid så sentralt, godt underbygd og bredt anlagt at den er høyaktuell for et stort publikum, fra berørte enkeltpersoner og alle som møter dem, til psykiatere og psykologspesialister.

Erfaringene fra klinisk praksis tilsier at mange behandlere opplever usikkerhet i møte med barn av psykisk syke, ikke minst når barnet har mistet en av foreldrene i selvmord. Vi kan slå oss til ro med at vi tror barnet er ivaretatt eller ikke vil komme til samtale (1). Denne boken viser tydelig at adekvat oppfølging av barn etter selvmord både er avgjørende og innen rekkevidde for de aller fleste som møter dem. Både støttenettverk og behandlere vil kunne hente øt forståelse og trygghet. Noe av styrken i formidlingen ligger $i$ at de enkle grepene illustreres så levende, og at de mer komplekse tiltakene beskrives så tilgjengelig.

Teori og forskning presenteres i alle de seks kapitlene (introduksjon, utfordringer, støtte, mestring, post-traumatisk vekst og faglige implikasjoner - beste praksis). Vi finner også noen norske referanser, som Dyregrov \& Dyregrov og Sveen \& Walby. Både det generelle inntrykket og disse referansene understøtter bokens aktualitet for norske forhold. Vi blir godt kjent med historiene til de fleste av deltakerne fra studien gjennom utdrag som illustrerer teori, forskning og erfaringer fra Camp HOPE, men også gjennom en samlet presentasjon etter hvert deltema.

Omslaget er representativt for bokens hovedbudskap om håp mørket ser ut til å overskygge, men iblandes gradvis alle nyanser, slik at lyset bryter igjennom. De 16 hovedhistoriene vi får del i, konkluderer alle med håp og vekst til tross for svært ulike situasjoner rundt selvmordet, støttenettverk og belastninger i ettertid. Dette er medrivende lesning til ettertanke.

\footnotetext{
Nina Helene Alnes

Overlege, Voksenpsykiatrisk avdeling Vinderen

Diakonhjemmet sykehus

Litteratur

1. Alnes NH. Barn har ikke tid til å vente. Tidsskr Nor Legeforen 2011; 131 . 1541-2.
} 